\title{
The subprime crisis and Islamic stock markets integration
}

\author{
Bakri Abdul Karim \\ Faculty of Economics and Business, UNIMAS, Samarahan, Malaysia \\ Nor Akila Mohd. Kassim \\ Faculty of Business Management, UiTM, Shah Alam, Malaysia, and \\ Mohammad Affendy Arip \\ Faculty of Economics and Business, UNIMAS, Samarahan, Malaysia
}

\begin{abstract}
Purpose - The purpose of this paper is to examine the effects of the current global crisis on the integration and co-movements of selected Islamic stock markets.

Design/methodology/approach - Time series techniques of cointegration were used over the period spanning from February 15, 2006 to December 31, 2008. In order to explore changes in the stock market integration and co-movement, following Majid and Kassim, we divide the period of analysis into two periods, namely the pre-crisis period (February 15, 2006-July 25, 2007) and during crisis period (July 26, 2007-December 31, 2008).

Findings - No evidence was found of cointegration among the Islamic stock markets in both periods. Accordingly, the 2007 subprime crisis does not seem to affect the long-run co-movements among the Islamic stock markets.

Practical implications - The Islamic stock markets provide opportunity for the potential benefits from international portfolio diversification, even after the subprime crisis. The prohibition of riba, gharar and maysir is one of the plausible reasons of no cointegration in the Islamic stock markets.

Originality/value - Using the Islamic stock indices, to the best of the authors' knowledge, goes clearly beyond the existing literature on the subject matter.
\end{abstract}

Keywords Islam, Stock markets, Portfolio investment, Diversification

Paper type Research paper

\section{Introduction}

As a result of financial globalization and liberalization, the degree of financial markets integration around the world increased significantly in 1980s and 1990s. For example, Blackman et al. (1994) found that the degree of market integration among 17 countries had increased more in 1980s than in the 1970s. The impact of the October 1987 stock market crash and the 1997 Asian financial crisis on stock market integration has drawn much attention among economists and practitioners. Lee and Kim (1993) and Arshanapalli and Doukas (1993), have noted that the degree of integration among national stock markets has increased after the October 1987 stock market crash. Recently, Francis et al. (2002) and Yang et al. (2003) indicate that the short- and long-run relationships among equity markets were strengthened during the financial crisis of 1997 and become more integrated after the crisis. In addition, Hwahsin and Glascock (2006) investigated the stock market linkages between the USA and China, Hong Kong and Taiwan. They found evidence that stock markets became more cointegrated after the 1997 Asian financial crisis.

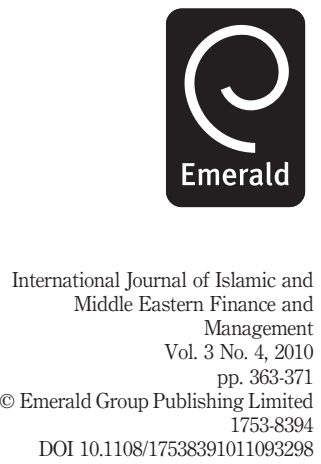

